\title{
TOWARDS THE ISSUE OF ESTIMATION OF THE CESIUM-137 DEPOSIT IN UPPER SOIL LAYER WHEN STUDING SOIL RUNOFF
}

DOI: http://dx.doi.org/10.18509/GBP.2020.85

UDC: 546.36:631.4]:551.311.234(470)

\author{
Lubov Trofimetz ${ }^{1}$ \\ Evgeny Panidi ${ }^{2}$ \\ ${ }^{1}$ Orel State University named after I.S. Turgenev, Russia \\ ${ }^{2}$ Saint Petersburg State University, Russia
}

\begin{abstract}
When the radiocesium method (detection of the Chernobyl origin cesium-137 radioactivity) is applied to determine soil losses on arable slopes during the postChernobyl period, the problem can be introduced as the benchmarking of the cesium (cesium-137) deposit measured in Bq/kg. The quantitative assessment of the soil runoff and runoff intensity is based correspondingly on computational models, which describe dependencies between the changes in the cesium deposit and the runoff parameters. Determination of the cesium deposit have to be carried out over the entire depth of the isotope penetration along the soil profile. However, our studies have shown that in the area of arable gray forest soils (in areas of outwashed soils of thalwegs and watershed surfaces) it is possible to determine the soil runoff intensity using data on the cesium deposit in the 0-20 (0-22) cm arable horizon.

We are describing the results of the accuracy estimation in the case of cesium specific radioactivity determining using the arable horizon soil samples. Comparison of the specific radioactivity of cesium in the $0-20 \mathrm{~cm}$ and $0-50 \mathrm{~cm}$ horizons shows that only in the accumulation zones the unaccounted part of the cesium deposit (deposit in under the $20 \mathrm{~cm}$ horizon) can achieve $32.8 \%$. In the areas of outwashed soils this unaccounted part is not exceed $16.2 \%$. Therefore, the specific radioactivity of gray forest soil (sampled in the thalwegs in a $0-20 \mathrm{~cm}$ horizon) can be used to estimate soil losses due to erosion on arable slopes.
\end{abstract}

Keywords: Soil Runoff, Surface Erosion, Radiocesium Method, Arable Horizon, Soil Sampling

\section{INTRODUCTION}

Radiocesium method is explored and applied to the study of soil runoff regime and soil losses on arable areas during recent decades, since Chernobyl accident brought significant artificial-origin cesium pollution in upper horizons of soil cover. The cesium deposit measured in $\mathrm{Bq} / \mathrm{kg}$ in particular sample of soil material can be compared with background radioactivity to estimate the intensity of soil outwash [4], [7], [8], [9], [10]. Our investigations provided in a couple of years are focused on study of the cesium redistribution in soil cover on arable area and its interdependencies on soil runoff amount in the regions of the central part of European Russia.

The study area (ground test site) is located in Orel region (central part of European Russia), to the north-west direction from Orel city $\left(53^{\circ} 0^{\prime} 2.33^{\prime \prime} \mathrm{N}, 35^{\circ} 57^{\prime} 35.10^{\prime \prime} \mathrm{E}\right)$. The area is covered by arable lands, and can be characterized as the territory with high soil erosion risk. 


\section{DATA AND METHODS}

To assess possible soil runoff estimation error that appears due to the lack of specific radioactivity accounting for the cesium under-arable horizon $(20-50 \mathrm{~cm})$ we compared intensity of soil runoff at the points using data collected on $0-50 \mathrm{~cm}$ soil horizon (horizon where the whole cesium deposit is accumulated) and on the $0-20 \mathrm{~cm}$ arable horizon. A comparative analysis of the cesium content in $0-20 \mathrm{~cm}$ horizon and deeper horizons was carried out then.

Digital Elevation Model (DEM) was derived from the topographic map of a 1:10,000 scale to ensure topography heights assimilation in further estimations and modeling. The spatial resolution of DEM and derived maps is $10 \mathrm{~m} /$ pix. Particularly, the catchment area [2] and profile curvature [3] gridded maps were produced basing on DEM data. Catchment area map reflects at each grid cell a potential area appeared to be the source of soil washed out of the area and collected in a cell location. Positions of the ancient ravine thalwegs are well identified on catchment area map by the local extrema values. Soil sampling was carried out in layer-by-layer manner in the thalwegs of the ancient ravines marked on catchment area map and in the thalwegs of modern streams formed in plowing furrows after plowing. These modern streams are identified clearly during the in-situ survey and sampling, and play significant erosion role on arable slopes together with ancient ravines.

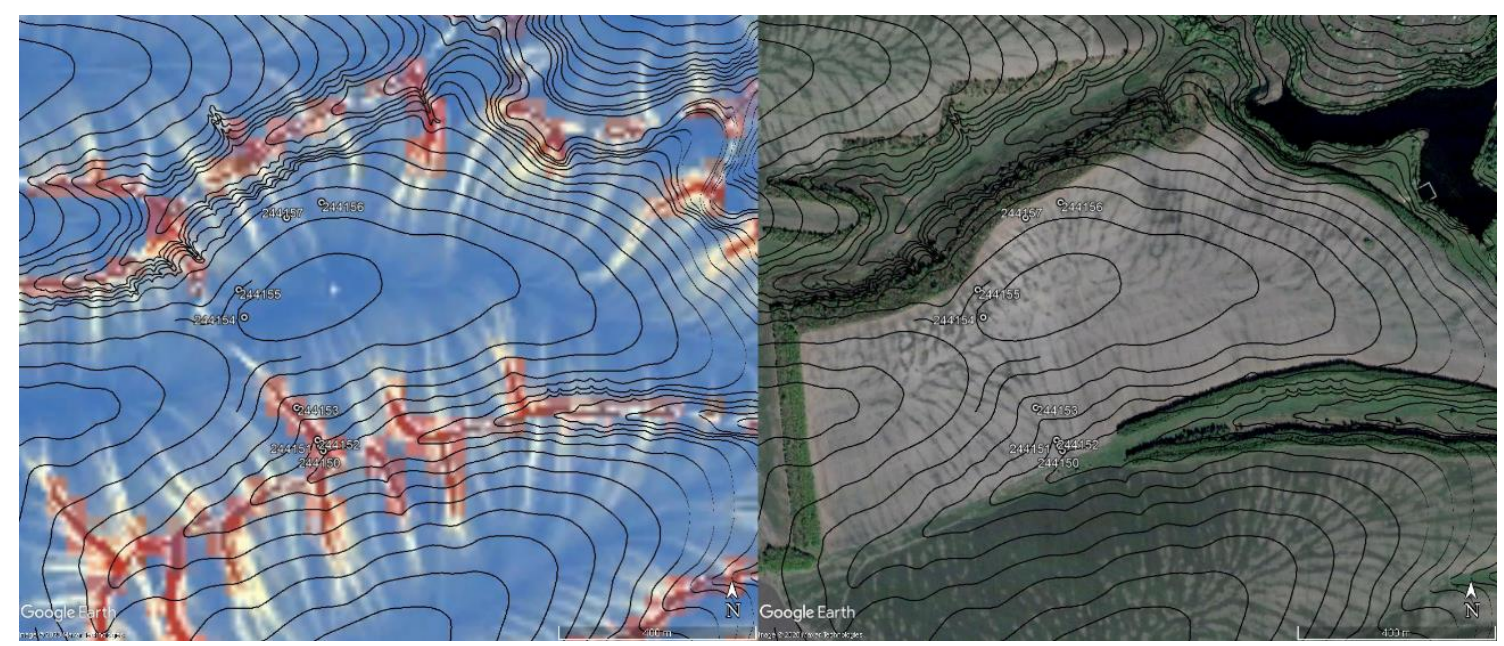

Figure 1. Fragment of the catchment area map (dark stripes of ancient ravine thalwegs over with bright tails that identify ravine origins unable to be recognized visually during in-situ observations) - on the left;

A fragment of satellite image of the study area (dark stripes highlight ancient ravines) - on the right (image (C) Google Earth); black curves are the isohypses

Soil sampling locations were selected accordingly to the erosion network structure on the study area (Figure 1). Point 244150 was allocated in the lower part of ancient ravine thalweg (at this point ancient thalweg is crossed also by a modern stream formed in the plowing furrow). Points 244151-244153 and 244155-244157 were allocated in the thalwegs of modern streams formed in plowing furrows. Point 244154 was allocated on the watershed.

\section{RESULTS AND DISCUSSION}

Results of in-situ data analysis presented in the Table 1 show that the unaccounted part of the cesium deposit stored in soil horizons deeper than 20-22 cm does not exceed $20 \%$ 
in the washout zones (convex slopes with positive or very small negative values of the profile curvature [6]). In other words, unaccounted part of the cesium deposit remains within the measurement error.

Table 1. Soil runoff in thalwegs formed in plowing furrows on summer-autumn of 2015

\begin{tabular}{|c|c|c|c|c|}
\hline $\begin{array}{l}\text { Sampling } \\
\text { point } \\
\text { number }\end{array}$ & $\begin{array}{c}\text { Class of soil runoff intensity } \\
\text { / Relief profile curvature } \\
\text { value* }\end{array}$ & \begin{tabular}{|} 
Specific \\
radioactivity of \\
cesium-137 in $0-$ \\
$20 \mathrm{~cm}$ arable soil \\
horizon, $\mathrm{Bq} / \mathrm{kg}$ \\
\end{tabular} & $\begin{array}{c}\text { Specific radioactivity of } \\
\text { cesium-137 in soil horizon } \\
\text { under the } 20 \mathrm{~cm}, \mathrm{~Bq} / \mathrm{kg} / \\
\text { percentage in full cesium-137 } \\
\text { deposit at a sampling point, } \%\end{array}$ & $\begin{array}{l}\text { Soil runoff } \\
\text { intensity, } \\
\text { ton/ha } \\
\text { per year }\end{array}$ \\
\hline 244150 & Outwashed / $-0.003^{2}$ & 112.3 & $37.2 / 12.0$ & 28.8 \\
\hline 244151 & Strongly outwashed / $0.002^{3}$ & 29.9 & $0.0 / 0.0$ & 63.8 \\
\hline 244152 & Strongly outwashed / $0.002^{3}$ & 42.4 & $13.7 / 16.2$ & 58.5 \\
\hline 244153 & Outwashed / $-0.0004^{1}$ & 82.8 & $30.8 / 4.0$ & 41.3 \\
\hline 244154 & Inwashed / -0.0003 & 119.0 & $116.2 / 32.8$ & 25.9 \\
\hline 244155 & Outwashed / $-0.0002^{1}$ & 60.6 & $6.23 / 9.3$ & 50.8 \\
\hline 244156 & $\begin{array}{l}\text { Outwashed, degraded, at } \\
\text { watershed / } 0.0004^{3}\end{array}$ & 94.0 & $36.3 / 16.2$ & 36.6 \\
\hline 244157 & Outwashed / $0.0005^{3}$ & 70.9 & $6.78 / 4.6$ & 30.2 \\
\hline
\end{tabular}

* Negative values of profile curvature generally mark inwash (accumulation) zone, while positive mark outwash zone; 1 - small negative values of profile curvature mark - plain or low-concave area; 2 - accumulation zone (concave area) crossed by modern stream (aggressive erosion structure); 3 - outwash zone (convex area).

Only the sampling point 244154 showed that the cesium content in the horizon deeper than $20 \mathrm{~cm}$ was estimated as $32.8 \%$ of the total cesium deposit. However, this sampling point is located in the watershed zone (Fig. 1). The negative value of the profile curvature $(-0.0003)$ and the position on watershed are indicate the surrounding of the sampling point to be local accumulation zone. Slightly concave surface and small slope gradient cause a small flow energy. The stream forms a thalweg here, but energy of the stream is not enough to wash soil out. The soil at sampling point 244154 pan be classified as inwashed or outwashed-inwashed. Soils of the watershed surface can be denoted also as degraded [5], while in the conditions of a horizontal flat surface the soil is plowed deeper and has no inwash from upper slope sections, so the organic material is washed out with higher intensity.
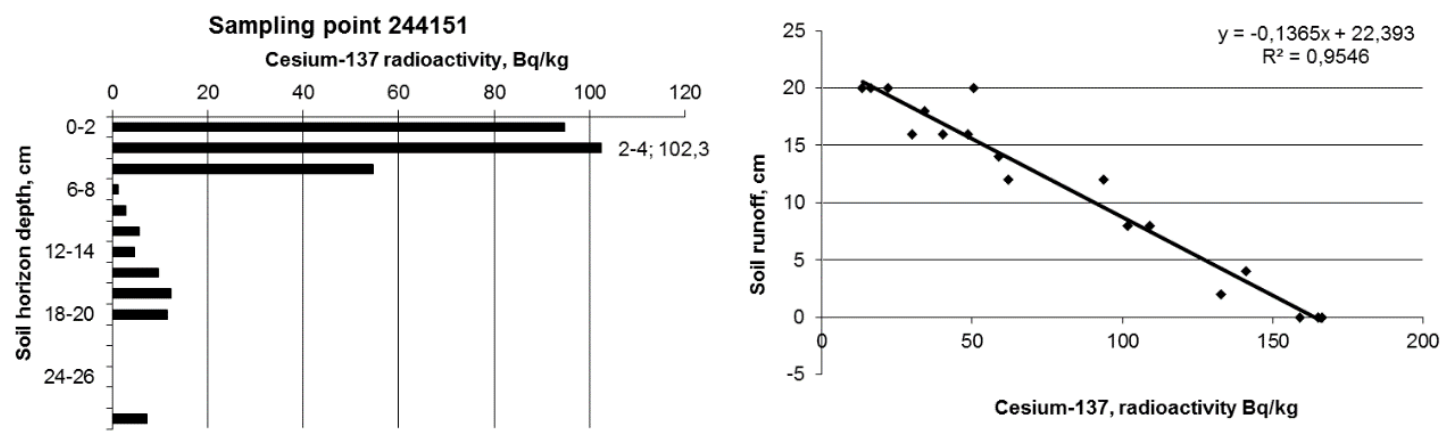

Figure 2. Distribution of cesium-137 radioactivity values by soil horizons in the stream thalweg at sampling point 244151 - on the left; Dependence of soil runoff (outwashed layer in $\mathrm{cm}$ ) on cesium137specific radioactivity at the locations of layer-by-layer soil sampling in 2015 (samples collected in zones of degraded soils are excluded as violating the data series homogeneity) - on the right

Positive profile curvature values at sampling point locations (from 0.0005 to 0.002 ) identify convex slope sections and outwashed soils. All other sampling points with 
negative profile curvature (from -0.0002 to -0.0006) are located on the slope not on the watershed, but can be classified also as outwash zone markers, as the values of the profile curvature being negative have very small absolute values. Consequently, the surface at these points is almost flat or very slightly concave. Particularly, table analysis shows that outwashed soils are formed on the convex slope sections, and at the slope base in the accumulation zone where modern stream formed in the plowing furrow intersects the ancient ravine (sampling point 244150).

Figure 2 shows an example of cesium radioactivity distribution diagram by $2 \mathrm{~cm}$ soil horizons at sampling point 244151. The diagram shows that $16 \mathrm{~cm}$ of the $20 \mathrm{~cm}$ arable horizon was washed out. Unaccounted cesium deposit in horizons under the $20 \mathrm{~cm}$ is estimated as $2 \%$ of the total deposit at the point. Consequently, we can estimate the dependence of the washed soil layer (in $\mathrm{cm}$ ) on the specific radioactivity of cesium in the $0-20 \mathrm{~cm}$ soil horizon.

The dependencies shown in Figure 2 allow to consider the specific radioactivity of cesium measured in the $0-20 \mathrm{~cm}$ arable soil horizon as a compatible when estimating soil runoff. Consequently, we can apply so-called proportional model [9] to compute soil runoff intensity:

$$
R=10 \cdot B \cdot Z_{p} \cdot(A-1) /\left(t-t_{0}\right)
$$

Where, $R$ - soil runoff intensity in tons per hectare per year; $B$ - gray forest soil [1] density $\left(1110 \mathrm{~kg} / \mathrm{m}^{3}\right) ; Z_{p}$ - arable horizon thickness $(0.2 \mathrm{M}) ;\left(t-t_{0}\right)$ - number of years passed from Chernobyl accident till soil sampling; $A$ - the ratio of cesium-137 radioactivity in the integral soil sample to background radioactivity (background or reference radioactivity value was estimated as $180 \mathrm{~Bq} / \mathrm{kg}$ that is mean cesium-137 radioactivity on the block elevations at the watershed of southern exposure slope) $; 10-\mathrm{kg} / \mathrm{m}$ to ton/ha conversion coefficient.

Since the highest rates of soil radioactivity in the pre-Chernobyl period did not exceeded $10 \mathrm{~Bq} / \mathrm{kg}$, the accounting of military origin cesium can be excluded from computations [4].

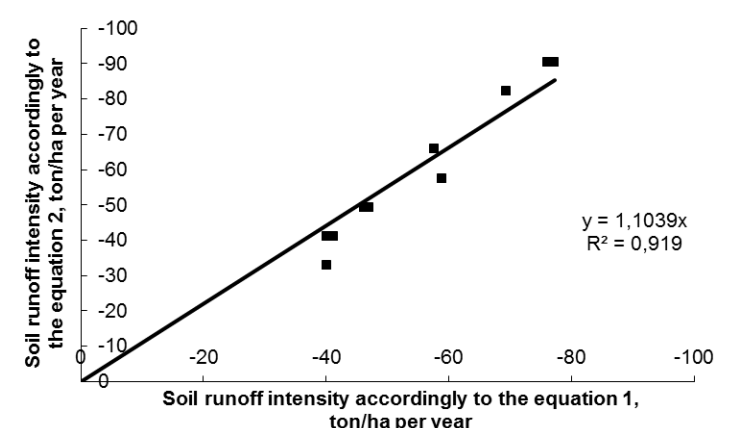

Figure 3. Interdependence of soil intensity estimated using integral and layer-by-layer radiological analysis of soil samples

Allocation of an outwashed soil layer in diagrams equal to the one shown in Figure 2 (we have 20 layer-by-layer soil samples collected in 2015 in the study area described) allowed us additionally to compute the soil runoff intensity at the sampling point locations using the Equation 2:

$$
I_{\text {ton } / \text { ha }}=I_{m / \text { year }} \cdot 10000 \cdot 1110
$$


Where, Iton/ha - soil runoff intensity in tons per hectare per year, computed as a quotient of the outwashed soil layer height (16 cm in Fig. 2) division for the number of years from 1986 to 2015 (27 years); 10000 - square meters to hectares conversion coefficient; 1110 $\left(\mathrm{kg} / \mathrm{m}^{3}\right)$ - gray forest soil [1] density.

A high correlation between outwashed soil layer value at the sampling point and specific radioactivity of cesium in the soil sample ( 0.98 for measurements presented in Figure 2 ) resulted in a high correlation between the intensity of soil runoff estimated using Equations 1 (basing on specific radioactivity of cesium in the $0-20 \mathrm{~cm}$ soil horizon) and 2 (basing on results of layer-by-layer radiological analysis of soil sample) - Figure 3, The correlation value is 0.96 .

\section{CONCLUSIONS}

Arable soil horizon $(0-20 \mathrm{~cm})$ is used to collect radiological and agrochemical samples when providing agricultural monitoring. For the soil outwash area (zone of a convex or very slightly concave relief surface), understatement of the cesium-137 deposit in an integral soil sample collected in $0-20 \mathrm{~cm}$ soil horizon does not exceed $20 \%$. Therefore, it is possible to use soil samples collected in this horizon (horizon of maximal penetration of cesium-137) when providing mass sampling in stream thalwegs formed in ancient ravines and plowing furrows to assess the intensity of erosion processes. In the accumulation zones, errors will exceed 20\%; however, the task of soil runoff assessment is not set usually in these zones.

In accumulation zone at the slope base, the streams can cross and erode sediment plume. In such cases, the soil runoff intensity in thalwegs of these streams appears almost the same as in the convex sections of slope.

Additionally, the dependencies for a watershed section of the arable slopes (where degraded soils are presented) have to be explored in future.

\section{REFERENCES}

[1] Alifanov V.M., Gugalinskaya L.A., Ovchinnikov A.Y. Paleocriogenesis and diversity of soils in the central part of the East European plain. Moscow, GEOS, 2010, 160 p. (In Russian)

[2] Costa-Cabral M.C., Burges S.J. Digital Elevation Model Networks (DEMON): A model of flow over hillslopes for computation of contributing and dispersal areas. Water Resources Research, 1994, Vol. 30, Issue 6, pp. 1681-1692. doi:10.1029/93WR03512

[3] Evans L.S. General geomorfometry, derivatives of altitude, and descriptive statistics. In: Chorley R (ed.), Spatial Analysis in Geomorphology (London, Methuen), 1972, pp. 17-90

[4] Golosov V.N., Kvasnikova E.V. Erosion impact onto in-landscape radionuclide migration. Radioactivity of nuclear explosions and accidents: proceedings of the international conference, April 24-26, 2000, Moscow, 2000, Vol. 1, pp. $733-741$ (in Russian)

[5] Marusova E.A. Influence of natural and anthropogenic factors onto the arable gray forest soils characteristics of the southern part of Moscow region. Dissertation, Moscow state University, 2005, 147 p. (in Russian)

[6] Moore I.D., Gessler P.E., Nielsen G.A., Peterson G.A. Soil attribute prediction using terrain analysis. Soil Science Society of America Journal, 1993, Vol. 57, Issue 2. pp. 443-452.

[7] Panidi E., Trofimetz L, Sokolova J. Application of phyto-indication and radiocesium indicative methods for microrelief mapping. IOP Conference Series: Earth and Environmental Science, 2016, Vol. 34, Issue 1, Article number 012024, 6 p. doi:10.1088/1755-1315/34/1/012024 
[8] Panidi E., Trofimetz L., Sokolova J., Kunaeva E. Large-scale indicative mapping of soil runoff. International Archives of the Photogrammetry, Remote Sensing and Spatial Information Sciences, 2017, Vol. XLII-3/W2, pp. 175-178. doi:10.5194/isprs-archives-XLII-3-W2-175-2017

[9] Walling D.E., He Q. Improved models for estimating soil erosion rates from cesium-137 measurements. Journal of Environmental Quality, 1999, Vol. 28, Issue 2, pp. 611-622. doi:10.2134/jeq1999.00472425002800020027x

[10] Zapata F. (ed.) Handbook for the Assessment of Soil Erosion and Sedimentation using Environment Radionuclides. Kluwer Academic Publishers, 2002, 220 p. 